JMEWS • Journal of Middle East Women's Studies • 15:2 July 2019

Al-Rasheed $•$ The Long Drive to Prison • Third Space

\title{
Third Space
}

\section{The Long Drive to Prison}

\section{The Struggle of Saudi Women Activists}

Madawi Al-Rasheed

I learned to drive in Lebanon when I was seventeen years old. My father left Saudi

Arabia for political reasons in 1975. I was exhilarated to drive myself to the American

University of Beirut, in what was a divided city at the time following several years of civil war. My excitement was short-lived as I ventured alone into rather dangerous neighborhoods. A clumsy and not very confident young driver, I carefully navigated the multiple checkpoints set up by various militias. Very quickly I came face-_to--face with aggressive and impatient male drivers whizzing around the city. The civil war had turned many Lebanese men into unruly drivers, always in a hurry to reach their destination before the snipers and the bombs took their toll. On one occasion, early in my driving experience, I was trying to get out of a narrow and congested alley with great difficulty. Behind me was a very impatient taxi driver, who got out of his car and approached me. Thinking that he was going to help me get out of my paralyzed situation, I opened my window to talk to him. He was shouting and cursing. I explained that I was a novice, but to no avail. Listening to my accent, he immediately recognized me as a Saudi. He came close to my car and showered me with very vulgar insults, all derivatives of male and female body parts. I closed my window and wiped away the tears that had beguan to roll down my cheeks.

I returned to Saudi Arabia for a brief moment in the late 1980s. Having survived the onslaught of the Lebanese drivers and the bumpy roads that had become war zones, I now considered myself an experienced navigator of difficult situations. I 
felt frustrated not being able to drive myself around Riyadh to run errands and visit family and friends. I was grounded and always dependent on a male driver, for whom I developed a dislike. He was always late and inquisitive. My paranoia was -lay in not finding him after he dropped me off in the marketplace. There were no mobile phones in those days. Because I was Gcovered in a black abaya, including my face, he couldn't recognize $m_{2}$ and the burden fell on me to find him among the many drivers who always gathered outside shops waiting to collect their employers. He was never there. Waiting for him even for five minutes alone outside the shops of al-Wazir

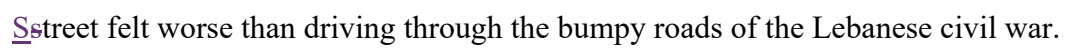
Inquisitive men, either shopping or just hanging $\operatorname{around}_{2} ;$ the odd invitation to get into other cars $_{2} ;$ the flying cards with male names and phone numbers ${ }_{2} ;$ and the occasional insults for being a young unaccompanied woman standing alone-in the street ${ }_{-}=$ always a suspicious person ${ }_{5}=$ interrupted my wait and added to my anxiety. Having survived the Lebanese experience, I learned to develop a body posture and a female piercing gaze through the holes of my facial veil that I believed would frighten even the most aggressive intruder into my limited waiting area in an all-male_-dominated space.

On June 24, 2018, came the historic moment when women in Saudi Arabia were allowed to drive. Since the 1990s; women had been campaigning to lift the ban on driving. This was one of their goals $s_{2}$ but their aspirations went further than the steering wheel. They demanded full citizenship, above all equality and respect as women in a country that continued to see them as minors in need of a guardian in order to live their lives.

Many women were exhilarated just like-as I was when I occupied the driving

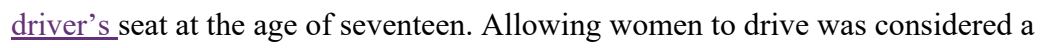


symbolic gesture pointing in the direction of promised freedoms, equality ${ }_{2}$ and respect. Just days before lifting the ban on driving, several leaders of the nascent Saudi feminist movement were arrested and charged with a series of vague aceusans ranging from a series of vague charges, including contact with foreign embassies, being agents of foreign enemy governments, and recruiting subversive underground cells. The hand that had given them the long-awaited right to drive had taken away the basic freedoms of those courageous women who had campaigned for full inclusion, gender equality ${ }_{2}$ and an end to subordination. Since June 24 , the list of detained women has then letainees, there were women I knew and wrote about in several books and articles:- Hatoun al-Fassi, Iman al-Nafjan, Aziza al-Yousef, and many other veteran and young activists found disappeared into the prisons of the Saudi regime. How can the current crown prince, young Muhammad ben Salman, constructed by the Western press and the regime's propaganda industry as the greatest revolutionary reformer, give women the right to drive and take away the freedom of those who had been behind the campaign to reach this symbolic victory?

I was not puzzled, surprised, or bewildered by the contradictions. In A Most Masculine State (Al-Rasheed 2013), I analyzed gender and politics in Saudi Arabia and reached the conclusion that repressive regimes, such as that in Saudi Arabia, are keen to be seen as emancipators of women, given that they depend heavily on Western protection and economic ties to weather domestic and regional challenges. The Saudi regime needs women for both domestic politics and international recognition.

Domestically, the regime ironically needs women to weaken local dissent. Given that Saudi women proved to be well-_organized and strongly determined 
activists, the regime wanted to co-opt their mobilization and use them against its many enemies. The regime uses women as a force to divide society and weaken solidarity. The regime wants women to be-enlisted in its war against Islamists and other dissenters. Nothing satisfies an authoritarian government more than a gender war; such as the one that has raged in the kingdom for decades. Muhammad ben Salman, like other Saudi monarchs, presents himself as a champion of women's rights against the radical and oppressive Islamists. As Saudi gender policies appeared to be a milder version of those practiced under the rule of the Islamic State in Iraq and Syria, it became urgent for the regime to distance itself from that ugly model of Islamism. Yet, in reality the Saudi strategy of using Islam as a justification for gender discrimination provides the blueprint and the source of inspiration for latter-day bigoted policies of many radical Islamist movements.

Internationally, since 9/11 the Saudi regime has been under pressure to lessen the obvious and visible restrictions on women. In order to silence critical voices in the West, the crown prince was compelled to allow women limited freedoms $s_{2}$ from driving to watching football matches and concerts. Drawing international capital to the Saudi market in a post-oil economy is very much dependent on gender equality and the visibility of women in the labor force. However, the impact of high-profile actions, such as the limited appointment of women to senior government positions, will definitely fade away unless accompanied by real political reform. After all, appointments do not always translate into empowerment, as other Arab women across the region have discovered across the region.

Women calling for women's rights have been occasionally tolerated in the kingdom provided their demands are limited. Yet, even this option is no longer available to Saudi women under Muhammad ben Salman. The pervasive arrest of 
women activists in the summer of 2018 attests to a sinister policy of silencing all dissenting voices. However, women in the driving driver's seat are better equipped to continue the struggle for equal citizenship, as I learned at age seventeen.

Both men and women need a secure environment, free of the threat of arrest to continue the struggle for real political rights, representative government ${ }_{2}$ and the rule of law. The international community should play a role in pushing the kingdom towards more democratic forms of governance and should make economic and military cooperation with the regime dependent on compliance with international human--rights norms and values. With most women activists in prison, no doubt the struggle of Saudi women will continue, assisted by the welcome and broad support of the international women's movement and NGOsnongovernmental organizations. However, this is not enough. Western governments should not celebrate the so-called historic driving moment and ignore the plight of detained women activists, such as the latest detainee Samar Badawi, who have impressed the international community by $\underline{\text { with }}$ their resilience and perseverance.

Three options are available under severe repression: remain silent, as do the majority; flee the country, an increasing alternative; or continue the struggle and eventually face prison. I have been forced to choose the second option in order to entinue to pursue my own agenda of writing critically and constructively about political and social issues that affect both men and women under authoritarian rule. I am humbled by those in the third category, who have bravely endured first the risk and then the reality of imprisonment.

The memory of the wild celebrations on June 24 are-is beginning to fade away under the new terror associated with the rule of the crown prince. However, having 
opened this particular Ppandora's box, even the greatest repression will fail to

diminish the momentum of the movement that has been created.

Madawi Al-Rasheed is a-visiting professor at the Middle East Centre at the London School of Economics. She is the-author of A Most Masculine State (2013) -and Muted Modernists (2015).Her latest book, and Salman's Legacy: The Dilemmas of a New Era in Saudi Arabia was portished in-(2018). Contact: m.al-rasheed@1se.ac.uk\{Au: _ _ _. - Formatted: Font: 9 pt, Bold Please supply your email address.

\section{Reference}

Al-Rasheed, Madawi. 2013. A Most Masculine State: Gender, Politics and Religion in Saudi Arabia. Cambridge: Cambridge University Press. 